\title{
Pension beneficiaries' household food insecurity and associated factors in Debre Markos town, Northwest Ethiopia
}

\author{
Yawukal Chane ${ }^{1}$, Getachew Hailu ${ }^{2}$ and Gemechu Kumera ${ }^{2 *}$
}

\begin{abstract}
Objectives: A community based cross-sectional study was conducted from March to April, 2016 in Debre Markos town, Northwest Ethiopia to assess the level of household food insecurity and associated factors among pension beneficiaries.

Results: The overall prevalence of household food insecurity among pension beneficiaries' households was $82.5 \%$. Among food insecure households, $4.9 \%$ were labelled as mildly, $48.5 \%$ moderately and $46.6 \%$ severely food insecure. Living in rental house $(P=0.05)$, being younger beneficiaries $(P=0.001)$, low monthly household income $(P=0.001)$ and poor self-reported health status $(P=0.03$ ) were found significantly associated with household food insecurity. In conclusion, food insecurity was a public health problem among pension beneficiaries in the study area. The effort of the government to increase the pension benefit and making especial subsidy on food and health costs yield a longterm solution.
\end{abstract}

Keywords: Household food insecurity, Pension beneficiaries, Northwest Ethiopia

\section{Introduction}

Food security is a broad concept which involves conditions related to food supply and demand. Food security is defined as a state in which "all people at all times, have physical and economic access to sufficient, safe and nutritious food to meet their dietary needs and food preferences for an active and healthy life" [1, 2]. Food insecurity (FI) refers to limited or uncertain availability of nutritionally adequate and safe foods, or limited or uncertain ability to acquire food in socially acceptable ways [3].

Various studies conducted over years have provided evidence that FI is associated with a broad spectrum of health consequences [4-10]. FI is associated with malnutrition due to inadequate nutrient intake [9-14]. Previous studies also reported an association of FI with mental health problems [15-17], psychosocial dysfunction in children [18], compromised health status in the elderly

\footnotetext{
*Correspondence: geme.dmu@gmail.com

${ }^{2}$ Department of Public Health, College of Medicine and Health Sciences, Debre Markos University, Debre Markos, Ethiopia

Full list of author information is available at the end of the article
}

[19], and socio-familial problems [20] and poor quality of life $[21,22]$.

FI continues to be a major public health problem worldwide. Globally, over 800 million people do not eat enough food to live an active and healthy life [23, 24]. Therefore, FI is an ongoing public health issue in both developing and developed countries [25]. The vast majority of food insecured people live in developing countries $[26,27]$. Ethiopia is among the countries with high prevalence of household food insecurity (HFI). According to a baseline national food security survey by the Ethiopian Health and Nutrition Research Institute (EHNRI), 35\% of households in Ethiopia were food insecure [28]. Another study conducted in Addis Ababa reported that $75 \%$ of households were food insecure [29]. Studies conducted in Nigeria [30], Cape Town [31], Manitoba [32], Cambodia [33], India [34], Canada [35], and USA [36, 37] also reported high prevalence figures.

Despite the current inflation and high market instability in Ethiopia, pension beneficiaries have constant income of $30-70 \%$ of their monthly salary, since 2011 [38]. Despite this fact there was no such study which 
assessed the level of food insecurity among this vulnerable group in Ethiopia. The findings of this study contribute to the understanding of the factors at multiple spheres which are predictive of FI among the pension beneficiaries. Further, data on the level and factors associated with FI are needed for prioritizing, designing and initiating intervention programs aimed at improving food security status of the pension beneficiaries. Thus, the aim of this study was to provide information regarding the level and factors associated with household food insecurity among pension beneficiaries.

\section{Main text \\ Methods \\ Study setting}

A community based cross-sectional study design was employed to assess the level and associated factors of HFI among pension beneficiaries in Debre Markos town, Northwest Ethiopia from March to April, 2016. According to 2015 Population and Housing census, the population of Debre Markos town is projected to be 107,000 [39]. The study population was households with pension beneficiaries living in Debre Markos town.

\section{Sample size and sampling technique}

The sample size was determined using single population proportion sample size calculation formula with the inputs $95 \%$ confidence level, $5 \%$ of margin of error, non-response rate of $5 \%$ and a hypothesized proportion of HFI (P) $50 \%$. The required total sample size was 403. Households with at least one member of pension beneficiary were identified using names of individuals in the registration lists of a monthly pension payment payroll matching with their respective house numbers, documented in pensioners and social security affairs office of Debra Markos town [40]. A systematic random sampling technique was used to select study households using the house numbers. The sampling interval (K) was considered to be 8 since the total pension beneficiary households in the town were 3220 , and the required sample size was 403. Every 8th households of pension beneficiaries were included in the study, and the 4th listed household was identified as a random start with a lottery method for the subsequent selection until the required sample size of 403 was obtained.

\section{Data collection procedures}

A structured and pre-tested questionnaire was used for assessing potential determinants of FI. The parts of the questionnaire on HFI level was adopted from Food and Nutrition Technical Assistance (FANTA) indicator guide for Household Food Insecurity Access Scale (HFIAS) [41]. The questionnaire was administered in a local language (Amharic). The translated Amharic version (local language) was pre-tested prior to the actual survey and modifications were made accordingly. The content validity of the tool was checked against the conceptual framework of the study by relevant professionals. Reliability of the tool was checked using a test-retest method. Questions with less than 0.7 kappa or Pearson coefficient values were removed or revised.

\section{Data processing and analysis}

Data were entered into EPI INFO version 7 and analysed using SPSS version 20. Bivariate and multivariable logistic regression analysis were used to assess the relative effect of various explanatory variables on the dependent variable and to control potential confounders. Independent variables significantly associated with the dependent variable in bivariate regression models were exported to multivariable regression models for adjustment. The model adequacy was checked by using Hosmer and Lemeshow goodness of fit test. $P$ value $\leq 0.05$ at $95 \% \mathrm{CI}$ was considered statistically significant.

\section{Ethical consideration}

Ethical clearance was obtained from ethical review committee of Debre Markos University prior to data collection. Verbal consent was obtained from each study participants prior to participation in the study after detailed explanations about the purpose, benefit and the possible risks of the study. Nutrition education was given to all study participants.

\section{Results}

\section{Socio-demographic characteristics of study participants}

Table 1 summarizes socio-demographic characteristics of the study participants. Of 403 pension beneficiary households recruited, 395 were willing to take part in the study, with a response rate of $98 \%$.

\section{Health status, reason for pension and service year of study participants}

According to a self-reported health status, 23.3\% $(\mathrm{n}=92)$, $46.3 \%(n=183)$ and $30.4 \%(120)$ of study participants reported good, fair and bad health status, respectively. Reason for pension benefit for majority, 59.2\% $(n=234)$ of study participants was old age retirement pension. The median service year of study participants before retirement was 32 years, ranging between 2 and 55 years.

\section{Household income and expenditures}

The median monthly pension income was 350ETB (17.5 USD), which is equivalent to 0.58 US dollar per day. Nearly half of study participants, $46.3 \%(n=183)$ had monthly household income less than 33.3 USD. The 
Table 1 Socio demographic characteristics of pension receivers (study participants) in Debre Markos town, Northwest Ethiopia, 2016

\begin{tabular}{|c|c|c|}
\hline Characteristics & Frequency (n) & Percent (\%) \\
\hline \multicolumn{3}{|l|}{ Age (years) } \\
\hline $22-44$ & 39 & 9.9 \\
\hline $45-64$ & 180 & 45.6 \\
\hline $65-94$ & 176 & 44.5 \\
\hline \multicolumn{3}{|l|}{ Gender } \\
\hline Male & 141 & 35.7 \\
\hline Female & 254 & 64.3 \\
\hline \multicolumn{3}{|l|}{ Marital status } \\
\hline Married & 140 & 35.4 \\
\hline Not union & 26 & 6.6 \\
\hline Widowed & 229 & 58.0 \\
\hline \multicolumn{3}{|l|}{ Family size } \\
\hline$<4$ & 288 & 72.9 \\
\hline $5-9$ & 107 & 27.1 \\
\hline \multicolumn{3}{|l|}{ Educational status } \\
\hline Cannot read and write & 150 & 38.0 \\
\hline Can read and write & 39 & 9.9 \\
\hline Primary school & 65 & 16.4 \\
\hline Secondary school & 83 & 21.0 \\
\hline Certificate and above & 58 & 14.7 \\
\hline \multicolumn{3}{|c|}{ Occupation before retirement } \\
\hline Military & 53 & 32.7 \\
\hline Civil servant & 109 & 67.3 \\
\hline \multicolumn{3}{|l|}{ Current occupation } \\
\hline Employed & 68 & 17.2 \\
\hline Merchant & 24 & 6.1 \\
\hline Daily labourer & 28 & 7.1 \\
\hline Jobless & 275 & 69.6 \\
\hline
\end{tabular}

median monthly household income was 703 ETB (35.15 USD). Majority of the study participants, $78.3 \%(n=311)$ expend more than $75 \%$ of their monthly income on food.

The monthly median expenditure of households on food was 700ETB (35 USD). More than one-third of the study participants, $34.9 \%(\mathrm{n}=138)$ live in rental house. The households which had gardening accounts for only $17.2 \%(n=68)$ of the households sampled.

\section{Level of household food insecurity and Household access to food}

The overall prevalence of HFI among pension beneficiaries' households was (82.5\%). According to the scale, $46.6 \%(n=152)$ of households were classified as severely food insecure, while $48.5 \%(n=158)$ and $4.9 \%(n=16)$ of households were moderate and mildly food insecure, respectively. From a total household, only $19.2 \%(n=76)$ have never worried having enough food in the last 4 weeks (Table 2).
Table 2 Frequency distribution of responses to HFIAS items of study participants in Debre Markos town, Northwest Ethiopia, 2016

\begin{tabular}{|c|c|c|}
\hline Characteristics & Frequency (n) & Percent (\%) \\
\hline \multicolumn{3}{|c|}{ Worry not have enough foods } \\
\hline Yes & 319 & 80.8 \\
\hline No & 76 & 19.2 \\
\hline \multicolumn{3}{|c|}{ Unable to eat preferred foods } \\
\hline Yes & 317 & 80.3 \\
\hline No & 78 & 19.7 \\
\hline \multicolumn{3}{|c|}{ Eat a limited variety of foods } \\
\hline Yes & 312 & 79 \\
\hline No & 85 & 21 \\
\hline \multicolumn{3}{|c|}{ Eat some foods didn't want } \\
\hline Yes & 264 & 66.8 \\
\hline No & 131 & 33.2 \\
\hline \multicolumn{3}{|c|}{ Eat fewer meals in a day } \\
\hline Yes & 208 & 52.7 \\
\hline No & 187 & 47.3 \\
\hline \multicolumn{3}{|c|}{ Eat a smaller meal than needed } \\
\hline Yes & 258 & 65.3 \\
\hline No & 137 & 34.7 \\
\hline \multicolumn{3}{|c|}{ No food to eat of any kind } \\
\hline Yes & 92 & 23.3 \\
\hline No & 303 & 76.7 \\
\hline \multicolumn{3}{|c|}{ Go to sleep at night hungry } \\
\hline Yes & 88 & 22.3 \\
\hline No & 307 & 77.7 \\
\hline \multicolumn{3}{|c|}{ Go a whole day and night without eating } \\
\hline Yes & 46 & 11.6 \\
\hline No & 349 & 88.4 \\
\hline
\end{tabular}

\section{Factors associated with household food insecurity}

The multivariable logistic regression analysis revealed that age, monthly household income, house ownership, expenditure on food share, and health status were predictors of household food insecurity (Table 3).

\section{Discussion}

The current study provide evidence for the high level $(82 \%)$ of food insecurity among pension beneficiaries in Debre Markos town, Northwest Ethiopia. The findings are considerably higher than the level of national food insecurity (35\%) reported by the EHNRI [28]. The level of HFI reported in the current study is also higher than in previous study conducted in Addis Ababa (75\%) [29]. The higher level of FI in the current study could be due to low monthly income which is obtained from pension, and most of beneficiaries were survivor pensioners and unable to work or have less access to employment. The high level of FI in the present study might be partially 
Table 3 Factors associated with household food insecurity among pension beneficiaries in Debre Markos town, Northwest Ethiopia, 2016

\begin{tabular}{|c|c|c|c|c|c|}
\hline \multirow[t]{2}{*}{ Predictors } & \multicolumn{2}{|c|}{ Food insecurity } & \multirow[t]{2}{*}{$\operatorname{COR}(95 \% \mathrm{Cl})$} & \multirow[t]{2}{*}{ AOR $(95 \% \mathrm{Cl})$} & \multirow[t]{2}{*}{ P-value } \\
\hline & Yes & No & & & \\
\hline \multicolumn{6}{|l|}{ Age } \\
\hline $22-44$ & 9 & 86 & 1 & & \\
\hline $45-64$ & 28 & 80 & $0.29(0.13-0.65)$ & $0.18(0.06-0.50)$ & 0.001 \\
\hline$\geq 65$ & 31 & 160 & $0.54(0.25-19)$ & $0.26(0.10-0.70)$ & 0.007 \\
\hline \multicolumn{6}{|c|}{ Monthly household income (USD) } \\
\hline$<33.3$ & 1 & 182 & 1 & 1 & \\
\hline $33.3-112.1$ & 38 & 125 & $0.018(0.01-0.13)$ & $0.026(0.003-0.19)$ & 0.001 \\
\hline$>112.1$ & 30 & 19 & $0.003(0.003)$ & $0.006(0.001-0.053)$ & 0.001 \\
\hline \multicolumn{6}{|c|}{ Monthly food expenditure (\%) } \\
\hline$<75$ & 34 & 50 & 1 & 1 & \\
\hline$\geq 75$ & 35 & 276 & $5.36(3.06-9.39)$ & $3.33(1.56-7.12)$ & 0.002 \\
\hline \multicolumn{6}{|c|}{ Housing ownership } \\
\hline Own house & 60 & 197 & 1 & 1 & \\
\hline Government & 8 & 96 & $3.66(1.68-7.95)$ & $2.74(1.06-7.10)$ & 0.03 \\
\hline Private rent & 1 & 33 & $10(1.35-75.04)$ & $8.27(0.94-73.06)$ & 0.05 \\
\hline \multicolumn{6}{|c|}{ Self-reported health status } \\
\hline Good & 26 & 66 & 1 & 1 & \\
\hline Fair & 34 & 149 & $1.73(0.96-3.11)$ & $2.53(1.15-5.57)$ & 0.02 \\
\hline Poor & 9 & 111 & $4.85(2.15-11)$ & $3.10(1.14-8.45)$ & 0.03 \\
\hline
\end{tabular}

explained by high food inflation in the country during the past 2 years. Moreover, high dependency of households on food supplied by the market, and fluctuating food prices are contributing to higher FI among study participants.

Our findings illustrated a significant association between food insecurity and age of pension beneficiaries, such that older pension beneficiaries were less likely to be food insecure as compared to younger beneficiaries. Our findings are consistent with previous studies from the Andes [42], US, Canada and Australia [43, 44]. Possible explanations for these differences may be reliance on their son or daughter and spiritual or religious affiliations. Other possible explanation may be older beneficiaries may have less dependents and more mature families than younger, and mature families may be more likely to be food secure and economically stable because they have more adults to generate income. Furthermore, possibly older beneficiaries are no longer living independently in the community.

Low family monthly income was found to be negatively associated with food security. This finding is consistent with other studies conducted in Addis Ababa [29], Nigeria [30], Canada [32] and Australia [45, 46]. The study finding showed a positive impact of income on food security. This might be due to the reason that low monthly income diminishes the purchasing power of household consumption items. Further, income determines how much can be spent on various needs of the household.

Food share expenditure was the other predictor of FI in the study population. $\mathrm{HH}$ which expend more than $75 \%$ of their monthly income on food were at greater risk of being food insecured. Other studies in Bolivia, Burkina Faso, Philippines [47] and Manitoba [32] also reported parallel finding. The current study found that majority of the monthly income was spent on purchasing food and, even then, the prevalence of food insecurity was high among study participants. It might be due to the low income, where the amount spent on food may be insufficient to meet the food requirements of all the family members. This, in turn, may affect the food security status of the household. As the income decreases they intend to expend on food more than any other needs. Moreover, it might be partially explained by increasing price of food in the country during the past 2 years that led them to expend more of their income on food.

Households living in rental house were at greater risk of being food insecure as compared to those who had their own house. Our finding is consistent with previous research from Australia [46]. This might be due to the reason that pensioner who had their own house can rent some of their room and can earn income. It might be also due to the reason that the government rented house is given for more vulnerable pension beneficiaries. 
Self-reported poor or fair health was an independent predictor of HFI. Previous studies also supported the finding [32, 42, 46, 48-50]. Poor health condition may limit physical access to food in terms of of going the market, get to the store and to purchase, lifting, preparing and cooking meals at home [51]. Further, poor health status may impact upon their income and expenditures due to their inability to work, thus impacting their food security. However, as this study was cross sectional, it is not possible to determine whether poor health is a risk factor or an outcome of food insecurity.

\section{Conclusion}

The study findings provide evidence for the public health significance of food insecurity among pension beneficiaries' household in the study area. Living in rental house, being younger beneficiaries, low monthly income and self-reported poor/fair health status are key predisposing factors to food insecurity. The study findings provide evidence for the public health significance of food insecurity among pension beneficiaries' household in the study area. Living in rental house, being younger beneficiaries, low monthly income and self-reported poor/fair health status are key predisposing factors to food insecurity. Addressing the needs of the pension beneficiaries who are at greater risk of food insecurity will require a coordinated approach both nationally and at a local level. In order to mitigate this problem, the effort of the government to increase the pension benefit and making especial subsidy on food and health costs yield a long-term solution. Nutrition programs should recognize and provide services to cover pension beneficiaries needs. Social support and income generation strategies are also recommended. Ensuring employment opportunities will also have affirmative input. We also suggest national level study with strong study design.

\section{Limitations}

The major limitation of this study was the cross-sectional nature of its design as we can't establish causal relationships between the independent variables and household food insecurity. Secondly, recall bias and social desirability bias are potential limitations that may influence the HFIAS questions though attempt was made to minimize it by clarifying the purpose of the study. The health status was determined by using self report, which may not necessarily indicate their health status.

\section{Abbreviations}

EHNRI: Ethiopian Health and Nutrition Research Institute; ETB: Ethiopian Birr; $\mathrm{HH}$ : house hold; Fl: food insecurity; HDDS: household dietary diversity score;
HFI: household food insecurity; HFIAS: Household Food Insecurity Access Scale; FANTA: Food and Nutrition Technical Assistance.

\section{Authors' contributions}

YC, GH and GK participated in the study protocol development, data collection, analysis and write-up of the study. GK drafted and finalized the manuscript for publication. All authors read and approved the final manuscript.

\section{Author details \\ ${ }^{1}$ Department of Public Health, College of Medicine and Health Sciences, Hawassa University, Hawassa, Ethiopia. ${ }^{2}$ Department of Public Health, College of Medicine and Health Sciences, Debre Markos University, Debre Markos, Ethiopia.}

\begin{abstract}
Acknowledgements
Our sincere and deepest gratitude goes to Debre Markos University in supporting us with resource perspectives. Our gratitude also goes to the staffs of public health department who support us in supervision and monitoring of the data collection process and who give us a technical assistance for the successfulness of this study. Our special thank also goes to Ethiopian civil servant social security and Amhara credit and saving institution, Debre Markos branch. We are grateful for all study subjects who took part in the study.
\end{abstract}

Competing interests

The authors declare that have no any competing interests.

Availability of data and materials

The datasets supporting the conclusions of this article are included in the manuscript.

\section{Consent to publish}

Not applicable.

\section{Ethics approval and consent to participate}

Debre Markos University, College of Health science, Department of Public Health was approved the study protocol and then ethical clearance was obtained from ethical review committee of Debre Markos University prior to data collection. After explanation about the whole purpose of the study, further permission was obtained from Ethiopian civil servant social security, and Amhara credit and saving institution, Debre Markos branch. Verbal consent was obtained from each study participants prior to participation in the study after detailed explanations about the purpose, benefit and the possible risks of the study. Participants were told that they had full right to participate or not, and they were also informed that all the data obtained from them would be kept confidential using codes instead of any personal identifiers. Nutrition education was given to all study participants.

\section{Funding}

This study was supported by Debre Markos University for data collection material. However, it had no role in study design, analysis, decision to publish or preparation of the manuscript.

\section{Publisher's Note}

Springer Nature remains neutral with regard to jurisdictional claims in published maps and institutional affiliations.

Received: 5 May 2018 Accepted: 30 July 2018

Published online: 06 August 2018

\section{References}

1. FAO. Rome Declaration on World Food Security and World Food Summit Plan of Action. Rome (Italy): FAO; 1996.

2. Radimer KL, Olson CM, Campbell CC. Development of indicators to assess hunger. J Nutr. 1990;120(11s):1544-8.

3. Anderson SA. Core indicators of nutritional state for difficult-to-sample populations. J Nutr. 1990;120(11s):1557-600.

4. Gany F, Lee T, Ramirez J, Massie D, Moran A, Crist M, McNish T, Winkel G, Leng JC. Do our patients have enough to eat? Food insecurity among 
urban low-income cancer patients. J Health Care Poor Underserved. 2014;25(3):1153-68.

5. Kirkpatrick SI, McIntyre L, Potestio ML. Child hunger and longterm adverse consequences for health. Arch Pediatr Adolesc Med. 2010;164(8):754-62

6. Seligman HK, Bindman AB, Vittinghoff E, Kanaya AM, Kushel MB. Food insecurity is associated with diabetes mellitus: results from the National Health Examination and Nutrition Examination Survey (NHANES) 1999-2002. J Gen Intern Med. 2007:22(7):1018-23.

7. Shariff ZM, Khor G. Obesity and household food insecurity: evidence from a sample of rural households in Malaysia. Eur J Clin Nutr. 2005;59(9):1049-58.

8. Pérez-Escamilla R, Villalpando S, Shamah-Levy T, Méndez-Gómez Humarán I. Household food insecurity, diabetes and hypertension among Mexican adults: results from Ensanut 2012. Salud Publica Mex. 2014;56(1s):62-70.

9. Shen X, Gao X, Tang W, Mao X, Huang J, Cai W. Food insecurity and malnutrition in Chinese elementary school students. Br J Nutr. 2015;114(6):952-8.

10. Kim HJ, Oh K. Household food insecurity and dietary intake in Korea: results from the 2012 Korea National Health and Nutrition Examination Survey. Public Health Nutr. 2015;18(18):3317-25.

11. Cristofar SP, Basiotis PP. Dietary intakes and selected characteristics of women ages $19-50$ years and their children ages $1-5$ years by reported perception of food sufficiency. J Nutr Educ. 1992;24(2):53-8.

12. Kendall A, Olson CM, Frongillo EA. Relationship of hunger and food insecurity to food availability and consumption. J Am Diet Assoc. 1996;96(10):1019-24.

13. Rose $D$, Oliveira V. Nutrient intakes of individuals from foodinsufficient households in the United States. Am J Public Health. 1997:87(12):1956-61.

14. Tarasuk VS, Beaton GH. Women's dietary intakes in the context of household food insecurity. J Nutr. 1999:129(3):672-9.

15. Davison KM, Kaplan BJ. Food insecurity in adults with mood disorders: prevalence estimates and associations with nutritional and psychological health. Ann Gen Psychiatry. 2015;14(1):21.

16. Leung CW, Epel ES, Willett WC, Rimm EB, Laraia BA. Household food insecurity is positively associated with depression among low-income supplemental nutrition assistance program participants and incomeeligible nonparticipants1-3. J Nutr. 2014;145(3):622-7.

17. Howard LL. Does food insecurity at home affect non-cognitive performance at school? A longitudinal analysis of elementary student classroom behavior. Econ Educ Rev. 2011;30(1):157-76.

18. Kleinman RE, Murphy JM, Little M, Pagano M, Wehler CA, Regal K, et al. Hunger in children in the United States: potential behavioral and emotional correlates. Pediatrics. 1998;101(1):e3.

19. Vailas LI, Nitzke SA, Becker M, Gast J. Risk indicators for malnutrition are associated inversely with quality of life for participants in meal programs for older adults. J Acad Nutr Diet. 1998:98(5):548-53.

20. Hamelin A-M, Habicht J-P, Beaudry M. Food insecurity: consequences for the household and broader social implications. J Nutr. 1999;129(2):525-8.

21. Simmons LA, Modesitt SC, Brody AC, Leggin AB. Food insecurity among cancer patients in Kentucky: a pilot study. J Oncol Pract. 2006:2 (6):274-9.

22. Heflin CM, Siefert K, Williams DR. Food insufficiency and women's mental health: findings from a 3-year panel of welfare recipients. Soc Sci Med. 2005;61(9):1971-82

23. McGuire S, Food and Agriculture Organization of the United Nations, International Fund for Agricultural Development, World Food Programme. The state of food insecurity in the world 2015: meeting the 2015 International Hunger Targets: taking stock of uneven progress. Adv Nutr. 2015;2015(6):623-4.

24. De Haen $\mathrm{H}$. The state of food insecurity in the world 2003: monitoring progress towards the world food summit and millennium development goals. Rome (Italy): FAO; 2003

25. Gundersen C. Food insecurity is an ongoing national concern. Adv Nutr. 2013:4(1):36-41.

26. Food and Agriculture Organization of the United Nations, World Food Programme. The State of Food Insecurity in the World 2015. Meeting the 2015 international hunger targets: taking stock of uneven progress. Rome: Food and Agriculture Organization Publications; 2015. p. 2016.

27. Food and Agriculture Organization. Undernourishment around the World in 2012. Rome: Italy; 2012.

28. Ethiopian Health and Nutrition Research Institute. Nutrition baseline survey report for the National Nutrition Program of Ethiopia. Ethiopia: Ethiopian Health and Nutrition Research Institute; 2009.

29. Birhane T, Shiferaw S, Hagos S, Mohindra KS. Urban food insecurity in the context of high food prices: a community based cross sectional study in Addis Ababa, Ethiopia. BMC Public Health. 2014;14(1):680.

30. Babatunde R, Adenuga A, Adenuga O, Olagunju F. Ekiti State Social Security Scheme (ESSSS) and its effect on food security in Ekiti State, Nigeria. Int J Agric Sci Res Technol. 2013;3(1):45-52.

31. Battersby J. The State of urban food insecurity in Cape Town. Cape Town: Southern African Migration Programme; 2016.

32. Tonn NA. Food insecurity and self-reported psycho-social health status in Manitoba First Nation communities: results from the Manitoba First Nations Regional Longitudinal Health Survey 2002/2003. Winnipeg: University of Manitoba; 2012.

33. McDonald CM, McLean J, Kroeun H, Talukder A, Lynd LD, Green TJ. Correlates of household food insecurity and low dietary diversity in rural Cambodia. Asia Pac J Clin Nutr. 2015;24(4):720-30.

34. Chinnakali P, Upadhyay RP, Shokeen D, Singh K, Kaur M, Singh AK, et al. Prevalence of household-level food insecurity and its determinants in an urban resettlement colony in north India. J Health Popul Nutr. 2014;32(2):227-36.

35. Tarasuk V, Mitchell A, Dachner N. Household food insecurity in Canada, 2012: Research to identify policy options to reduce food insecurity. Toronto: PROOF; 2016.

36. Coleman-Jensen A, Gregory C, Singh A. Household food security in the United States in 2013 [Internet]. Washington (DC): Department of Agriculture, Economic Research Service, Economic Research Report No. 173; 2014. Available from: http://www.ers.usda.gov/media/1565415/err17 3.pdf. (cited 2018 April 05).

37. Coleman-Jensen A, Nord M. Food insecurity among households with working-age adults with disabilities. Washington, DC: USDA, Economic Research Service; 2013. Report No.: ERR-144.

38. Federal Negarit Gazzet of Federal Democratic Republic of Ethiopia. Public servants pension amendment of proclamation. Addis Ababa: Federal Negarit Gazzet of Federal Democratic Republic of Ethiopia; 2015.

39. Federal Democratic Republic of Ethiopia Central Statistical Agency. Population Projection of Ethiopia for all regions at Wereda level from 2014-2017. Addis Ababa: Federal Democratic Republic of Ethiopia Central Statistical Agency; 2013.

40. Ethiopian Public servants social security agency, Debre Markos Branch Office, 2008.

41. Coates J, Swindale A, Bilinsky P. Household Food Insecurity Access Scale (HFIAS) for measurement of food access: indicator guide. 34th ed. Washington, DC: Food and Nutrition Technical Assistance Project, Academy for Educational Development; 2007.

42. Leah J, Pradel W, Cole DC, Prain G, Creed-Kanashiro H, Carrasco MV. Determinants of household food access among small farmers in the Andes: examining the path. Public Health Nutr. 2013;16(1):136-45.

43. Ethiopian Public servants social security agency. Second growth and transformation (2008-2012) plan. Addis Ababa: Ethiopian Public servants social security agency; 2008.

44. Gorton D, Bullen CR, Mhurchu CN. Environmental influences on food security in high-income countries. Nutr Rev. 2010;68(1):1-29.

45. Temple JB. Food insecurity among older Australians: prevalence, correlates and well-being. Australas J Ageing. 2006;25(3):158-63.

46. Russell J, Flood V, Yeatman $H$, Mitchell P. Prevalence and risk factors of food insecurity among a cohort of older Australians. J Nutr Health Aging. 2014;18(1):3-8

47. Melgar-Quinonez HR, Zubieta AC, MkNelly B, Nteziyaremye A, Gerardo MFD, Dunford C. Household food insecurity and food expenditure in Bolivia, Burkina Faso, and the Philippines. J Nutr. 2006;136(5):1431-7. 
48. Stuff JE, Casey PH, Szeto KL, Gossett JM, Robbins JM, Simpson PM, Connell C, Bogle ML. Household food insecurity is associated with adult health status. J Nutr. 2004;134(9):2330-5.

49. Pheley AM, Holben DH, Graham AS, Simpson C. Food security and perceptions of health status: a preliminary study in rural Appalachia. J Rural Health. 2002;18(3):447-53.

50. Wolfe WS, Olson CM, Kendall A, Frongillo EA Jr. Understanding food insecurity in the elderly: a conceptual framework. J Nutr Educ. 1996;28(2):92-100.
51. Burns C, Bentley R, Thornton L, Kavanagh A. Reduced food access due to a lack of money, inability to lift and lack of access to a car for food shopping: a multilevel study in Melbourne, Victoria. Public Health Nutr. 2011;14(6):1017-23.
Ready to submit your research? Choose BMC and benefit from:

- fast, convenient online submission

- thorough peer review by experienced researchers in your field

- rapid publication on acceptance

- support for research data, including large and complex data types

- gold Open Access which fosters wider collaboration and increased citations

- maximum visibility for your research: over 100M website views per year

At BMC, research is always in progress.

Learn more biomedcentral.com/submissions 